\title{
Stress-reducing and anesthetic effects of the essential oils of Aloysia triphylla and Lippia alba on Serrasalmus eigenmanni (Characiformes: Serrasalmidae)
}

\author{
Ana Paula Gottlieb Almeida ${ }^{1}$, Tiago Gabriel Correia ${ }^{2,4}$, Berta Maria Heinzmann ${ }^{3}$, \\ Adalberto Luis $\mathrm{Val}^{4}$ and Bernardo Baldisserotto ${ }^{5}$
}

Anesthetic effect of Aloysia triphylla and Lippia alba essential oils (EOs) in the Amazonian fish Serrasalmus eigenmanni was evaluated. The fish were placed in aquaria containing A. triphylla or $L$. alba EOs ( 25 to $\left.200 \mu \mathrm{L} \mathrm{L}^{-1}\right)$. Then, fish were transferred to aquaria containing EO-free water to evaluate their recovery time. In another experiment, fish were transferred to aquaria containing A. triphylla or L. alba EOs ( 3 to $\left.10 \mu \mathrm{L} \mathrm{L}^{-1}\right)$ and swimming behavior was analyzed for up to $240 \mathrm{~min}$ of exposure. Water samples were collected at 0 and $240 \mathrm{~min}$ and blood samples were collected at $240 \mathrm{~min}$. Tested concentrations induced all stages of anesthesia, except $25 \mu \mathrm{L} \mathrm{L}^{-1}$ A. triphylla EO and $50 \mu \mathrm{L} \mathrm{L}^{-1} \mathrm{~L}$. alba EO, which only induced sedation. Prolonged exposure to both EOs reduced swimming time compared to the control at all evaluated times. The fish exposed to 3 $\mu \mathrm{L} \mathrm{L}^{-1}$ A. triphylla EO showed a lower net $\mathrm{K}^{+}$efflux compared to ethanol-exposed fish; in those exposed to $5 \mu \mathrm{L} \mathrm{L}^{-1}$, ammonia excretion was reduced. The blood parameters did not show significant differences between treatments. In conclusion, both EOs can be used as anesthetics and sedatives for transport of S. eigenmanni.

Keywords: Amazonian blackwaters, Anesthesia, Ion fluxes, Piranha, Stress.

Avaliou-se o efeito anestésico dos óleos essenciais de Aloysia triphylla e de Lippia alba no peixe amazônico Serrasalmus eigenmanni. Os peixes foram colocados em aquários contendo OEs de A. triphylla ou L. alba $\left(25\right.$ a $\left.200 \mu \mathrm{L} \mathrm{L}^{-1}\right)$. Após, foram transferidos para aquários com água sem anestésicos para avaliar o tempo de recuperação. Em outro experimento, peixes foram transferidos para aquários contendo OEs de A. triphylla ou L. alba $\left(3\right.$ a $\left.10 \mu \mathrm{L} \mathrm{L}^{-1}\right)$ e o comportamento natatório foi analisado até 240 min de exposição. Foram coletadas amostras de água em 0 e 240 min e de sangue em $240 \mathrm{~min}$. As concentrações testadas induziram todos estágios de anestesia, exceto $25 \mu \mathrm{L} \mathrm{L}^{-1} \mathrm{OE}$ de A. triphylla e $50 \mu \mathrm{L} \mathrm{L}^{-1} \mathrm{OE}$ de $L$. alba, que causaram somente sedação. Exposição prolongada a ambos OEs reduziu o tempo de natação comparado ao controle. Peixes expostos a $3 \mu \mathrm{L} \mathrm{L}^{-1} \mathrm{OE}$ de $A$. triphylla apresentaram menor efluxo de $\mathrm{K}^{+}$comparado aos expostos ao etanol e nos expostos a $5 \mu \mathrm{L} \mathrm{L}^{-1}$ a excreção de amônia reduziu. Parâmetros sanguíneos não diferiram entre tratamentos. Conclui-se que ambos OEs podem ser utilizados como anestésicos e no transporte de $S$. eigenmanni.

Palavras-chave: Águas negras amazônicas, Anestesia, Estresse, Fluxo iônico, Piranha.

\section{Introduction}

Stress can cause fish homeostasis loss, and it can be lethal if not reversed. Exposure to stressors is unavoidable in aquaculture because fish are routinely submitted to practices such as handling, transportation, and high stocking density, among others (Sampaio, Freire, 2016). Synthetic anesthetic substances have been used to prevent stress in fish (Small, 2003; Weber et al., 2009; Pramod et al., 2010). However, several of these substances can cause a loss of mucus, an increase of serum cortisol levels, immunosuppression, acidosis, tissue hypoxia (Sneddon, 2012; Zahl et al.,

\footnotetext{
${ }^{1}$ Programa de Pós-Graduação em Biodiversidade Animal, Universidade Federal de Santa Maria, Av. Roraima 1000, Camobi, 97105-900 Santa Maria, RS, Brazil. anapaulagottlieb@hotmail.com, Ohttps://orcid.org/0000-0003-4482-1890

${ }^{2}$ Departamento de Ciências Biológicas e da Saúde, Universidade Federal do Amapá, 68903-419 Macapá, AP, Brazil. correia.tg@gmail. com, Dhttps://orcid.org/0000-0002-1295-0543

${ }^{3}$ Departamento de Farmácia Industrial, Universidade Federal de Santa Maria, Av. Roraima 1000, 97105-900 Santa Maria, RS, Brazil. berta. heinzmann@gmail.com, Dhttps://orcid.org/0000-0002-6509-949X

${ }^{4}$ Laboratório de Ecofisiologia e Evolução Molecular, Instituto Nacional de Pesquisas da Amazônia, Av. André Araújo 2936, Petrópolis, 69080-971 Manaus, AM, Brazil. dalval@inpa.gov.br, Ohttps://orcid.org/0000-0002-3823-3868

${ }_{5}^{5}$ Departamento de Fisiologia e Farmacologia, Universidade Federal de Santa Maria, Av. Roraima 1000 Camobi, 97105-900 Santa Maria, RS, Brazil. bbaldisserotto@hotmail.com, Dhttps://orcid.org/0000-0002-8770-0100 (corresponding author)
} 
2012), and be aversive (Readman et al., 2013). Tricaine methanesulfonate (MS-222), the only anesthetic approved by the Food and Drug Administration for use in fish destined for consumption, induces hepatic lipoperoxidation in silver catfish Rhamdia quelen (Gressler et al., 2014). Due to these adverse effects, there has been an increase in research involving natural products such as essential oils (EOs), their isolated compounds and other types of extracts from plants to replace synthetic anesthetics (Mazandarani, Hoseini, 2017; Hoseini et al., 2018; Yousefi et al., 2018). Essential oils are permitted in organic aquaculture by the Food and Agriculture Organization of the United Nations (FAO) (Bansemir et al., 2006) and also by Brazilian legislation (MAPA, 2011).

Studies have shown the efficacy of anesthesia and/or the prevention of stress damage using EOs extracted from plants, such as: Ocimum gratissimum (Silva et al., 2012; Boijink et al., 2016), Hesperozygis ringens (Silva et al., 2013), Nectandra megapotamica (Tondolo et al., 2013), Hyptis mutabilis and Ocotea acutifolia (Silva et al., 2013). However, some EOs may have adverse effects. For example, the EO of Aloysia gratissima provoked involuntary muscle contractions during anesthesia induction and around $30 \%$ mortality up to $24 \mathrm{~h}$ later, besides not being safe for transport of the Brazilian flounder Paralichthys orbignyanus (Benovit et al., 2012). The EOs of L. alba and A. triphylla showed anesthetic efficacy and a stress-reducing effect in Centropomus parallelus (Parodi et al., 2016), R. quelen (Cunha et al., 2010; Parodi et al., 2014; Becker et al., 2016) and Hyppocampus reidi (Cunha et al., 2011), and did not induce aversiveness in fish (Bandeira Junior et al., 2018). Nevertheless, anesthesia with L. alba EO increased plasma cortisol of juvenile meagre, Argyrosomus regius (Cárdenas et al., 2016), indicating that the effect of a given EO may be species-specific. Almeida et al. (2018) demonstrated the anesthetic and sedative efficacy of A. triphylla and L. alba EOs in Serrasalmus rhombeus (Linnaeus, 1766), an Amazonian fish living in the blackwaters of the Negro River, but did not evaluate whether these EOs prevent stress damage, such as ionoregulatory and blood disturbances, when applied in blackwaters.

The Amazonian blackwaters have a high concentration of humic and fulvic acids from dissolved organic matter decomposition, resulting in an acidic $\mathrm{pH}$ close to 5.0-6.0 (Küchler et al., 2000; Mortatti, Probst, 2003; Matsuo, Val, 2007) and with an average annual temperature of $30.6{ }^{\circ} \mathrm{C}$ (Fonseca et al., 1982). Given that the $\mathrm{pH}$ and temperature of the water can affect anesthetic induction and recovery times (Gomes et al., 2011), the aim of this study was to evaluate whether A. triphylla and L. alba EOs can be used as anesthetics and transport stressreducing agents for Serrasalmus eigenmanni Norman, 1929, a species that can be found in the Amazonian blackwaters (Jégu, 2003; Dórea et al., 2004).

\section{Material and Methods}

Essential oil extraction and analysis. The plants $A$. triphylla and $L$. alba were cultivated at the campus of the Universidade
Federal de Santa Maria, in the city of Frederico Westphalen, southern Brazil. A voucher specimen (SMDB No. 11169) was deposited in the herbarium of the Biology Department. The EO extraction and analysis was made as described previously by Almeida et al. (2018). The main compounds of the EO of A. triphylla are geranial (24.3\%), limonene (21.7\%) and ciscarveol (Z-carveol) $(18.5 \%)$ and the main compounds of the EO of $L$. alba are linalool (66.3\%) and eucalyptol (10.6\%) (Almeida et al., 2018).

Animals. Specimens of S. eigenmanni (171.01 \pm 6.38 g; $18.26 \pm 0.39 \mathrm{~cm}$ ) (voucher number: INPA-ICT 53105) were collected during an expedition to Anavilhanas Islands of the Negro River, $110 \mathrm{~km}$ upstream from Manaus $\left(2^{\circ} 23^{\prime} 41^{\prime \prime} \mathrm{S}\right.$, $\left.60^{\circ} 55^{\prime} 14^{\prime \prime} \mathrm{W}\right)$. Fish were maintained in tanks supplied with flow through water, pumped directly from Negro River $\left(30^{\circ} \mathrm{C}\right.$, $\mathrm{pH}$ 5.1, dissolved oxygen levels 5-6 $\mathrm{mg} \mathrm{L}^{-1}$ ) and continuously aerated for a few hours before testing.

Experiment I: Anesthesia induction and recovery in $S$. eigenmanni exposed to $A$. triphylla and $L$. alba EOs. The fish were transferred individually to aquaria containing 5 $\mathrm{L}\left(30 \pm 0.81{ }^{\circ} \mathrm{C}, \mathrm{pH} 5.1 \pm 0.09\right)$ of water with the $L$. alba or A. triphylla EOs in the $25-200 \mu \mathrm{L} \mathrm{L}^{-1}$ concentration range, first diluted in ethanol at a proportion of 1:10. These concentrations were chosen based on a previous study with these EOs in $S$. rhombeus (Almeida et al., 2018). The time for anesthesia induction was evaluated according to Small (2003): stage I corresponds to sedation, when the reactivity to external stimuli is decreased; stage II involves the partial loss of equilibrium and erratic swimming, and stage III involves the total loss of equilibrium and the cessation of locomotion. In recovery, the fish returns to regular swimming and regular reactions to external stimuli. Eight fish were used for each tested concentration and each fish was only tested once. The maximum observation time was $15 \mathrm{~min}$; in the review by Hoseini et al. (2018), this period of time was enough in almost all experiments with fish to determine the time to induce deep anesthesia using essential oils. Control experiments were performed using aquaria containing only water and aquaria containing water and ethanol at a concentration equivalent to the highest dilution $\left(1800 \mu \mathrm{L} \mathrm{L}^{-1}\right)$. After the induction of anesthesia, fish were transferred to a tank containing only water to evaluate their recovery time. The animals were considered recovered when they showed regular swimming and regular reaction to external stimuli (i.e., when the peduncle caudal fin was pressed with a glass rod).

Experiment II: Prolonged exposure of $S$. eigenmanni to the $A$. triphylla and $L$. alba EOs. The fish were placed into tanks containing $15 \mathrm{~L}$ of water and A. triphylla (3 and $\left.5 \mu \mathrm{L} \mathrm{L}^{-1}\right)$ or $L$. alba $\left(5\right.$ and $\left.10 \mu \mathrm{L} \mathrm{L}^{-1}\right)$ EOs, first diluted in ethanol at a proportion of 1:10, and kept for 4 hours. Control experiments were performed using aquaria containing only water and aquaria containing water and ethanol at a concentration equivalent to the highest dilution $\left(90 \mu \mathrm{L} \mathrm{L}^{-1}\right)$. 
These concentrations were chosen based on the study of Almeida et al. (2018) with a related species, S. rhombeus. Three fish per aquaria were used for each concentration (three replicates for each concentration).

Behavioral analyses. The fish were filmed for $30 \mathrm{~s}$ for the analysis of the total swimming time and equilibrium (partial or total loss of equilibrium, or normal) at $0,5,30,60,120,180$ and $240 \mathrm{~min}$ of exposure.

Water sampling and analyses. Water samples were collected at $0,5,30,60,120,180$ and $240 \mathrm{~min}$ of exposure. The total ammonia levels were checked according to Eaton et al. (2005). The levels of $\mathrm{Na}^{+}$and $\mathrm{K}^{+}$were determined with a flame photometer (Analyzer) and the chloride levels were determined using the colorimetric method described by Zall et al. (1956). The net ion fluxes and ammonia excretion were calculated according to Val et al. (1998): Jnet (ammonia excretion $)=V\left([\text { ion }]_{1}-[\text { ion }]_{2}\right) \cdot(M . t)^{-1}$, where $[\text { ion }]_{1}$ and [ion $]_{2}$ are the ion or ammonia concentrations in the water in which the fish were kept at the beginning and at the end of the experimental period, respectively; $V$ is the volume of the water (in L); $M$ is the fish mass (in $\mathrm{kg}$ ); and $t$ is the duration of the exposure (in $h$ ).

Blood sampling and analyses. After 240 min of exposure to the EOs, fish were collected with a hand net, and held tightly with a wet cloth. Blood samples were collected through the caudal vein using heparinized syringes $(n=9$ per concentration). The blood was centrifuged for $5 \mathrm{~min}$ at 665.1 $g$ and the obtained plasma was frozen in liquid nitrogen. All samples were kept in a freezer at $-80^{\circ} \mathrm{C}$ until further analysis.

Plasma concentrations of cortisol (DBC Diagnostics Biochem Canada, ON, Canada) and total thyroxine $\left(\mathrm{T}_{4}\right.$; Symbiosys-Alka Tecnologia ${ }^{\circledR}$, SP, Brazil) were quantified in triplicate using the enzyme-linked immunosorbent assay (ELISA) method in a microplate reader (Molecular Devices, CA, USA). Lactate was determined by reacting the lactate dehydrogenase enzyme (LDH Kit-Sigma Diagnostics, St. Louis, MO, USA), according to Gutmann, Wahlefeld (1974). Total lipids concentration was determined by the colorimetric spectrophotometry method, according to Frings et al. (1972), using cod liver oil (Sigma Diagnostics, St. Louis, MO, USA) as the standard; the reaction was measured at $540 \mathrm{~nm}$. Total protein was determined by the colorimetric method described by Lowry et al. (1951), using bovine serum albumin (Sigma Diagnostics, St. Louis, MO, USA) as the standard; the reaction was measured at $625 \mathrm{~nm}$. Glucose was determined by the enzymatic colorimetric method based on the oxidase/ peroxidase reaction (Glucose LiquiColor Test-InVitro ${ }^{\circledR}, \mathrm{Fr}$ ).

Statistical analyses. All data were expressed as mean \pm standard error of the mean (SEM). The homogeneity of variances among treatments was tested using Levene's test. Anesthetic induction and recovery times and net ion flux comparisons between treatments were assessed using a parametric one-way ANOVA and Tukey test. When data violated the premises of ANOVA, the non-parametric KruskalWallis test was used for the comparisons of mean ranks. The comparisons between the different treatments and swimming time were assessed using the non-parametric Scheirer-RayHare extension of the Kruskal-Wallis test, followed by the post-hoc Nemenyi test. Analyses was performed using the Statistica 7.0 software (Stat Soft. Inc.). The minimum significance level was set at $\mathrm{P}<0.05$.

\section{Results}

The concentration of $25 \mu \mathrm{L} \mathrm{L}^{-1}$ A. triphylla $\mathrm{EO}$ and 50 $\mu \mathrm{L} \mathrm{L}^{-1} L$. alba $\mathrm{EO}$ only induced a sedative effect within 15 min; however, all other EO concentrations induced all stages of anesthesia. Fish exposed to 100 and $150 \mu \mathrm{L} \mathrm{L}^{-1}$ A. triphylla EO reached deep anesthesia (stage III) significantly faster than at lower concentrations, and the concentration of $100 \mu \mathrm{L}$ $\mathrm{L}^{-1}$ A. triphylla EO showed a lower recovery time (Fig. 1a). In the case of $L$. alba EO, fish reached stage III with 100 and $200 \mu \mathrm{L} \mathrm{L}^{-1}$; the recovery time did not differ between these concentrations (Fig. 1b). Exposure to $1800 \mu \mathrm{L} \mathrm{L}^{-1}$ ethanol alone did not produce any anesthetic effect.
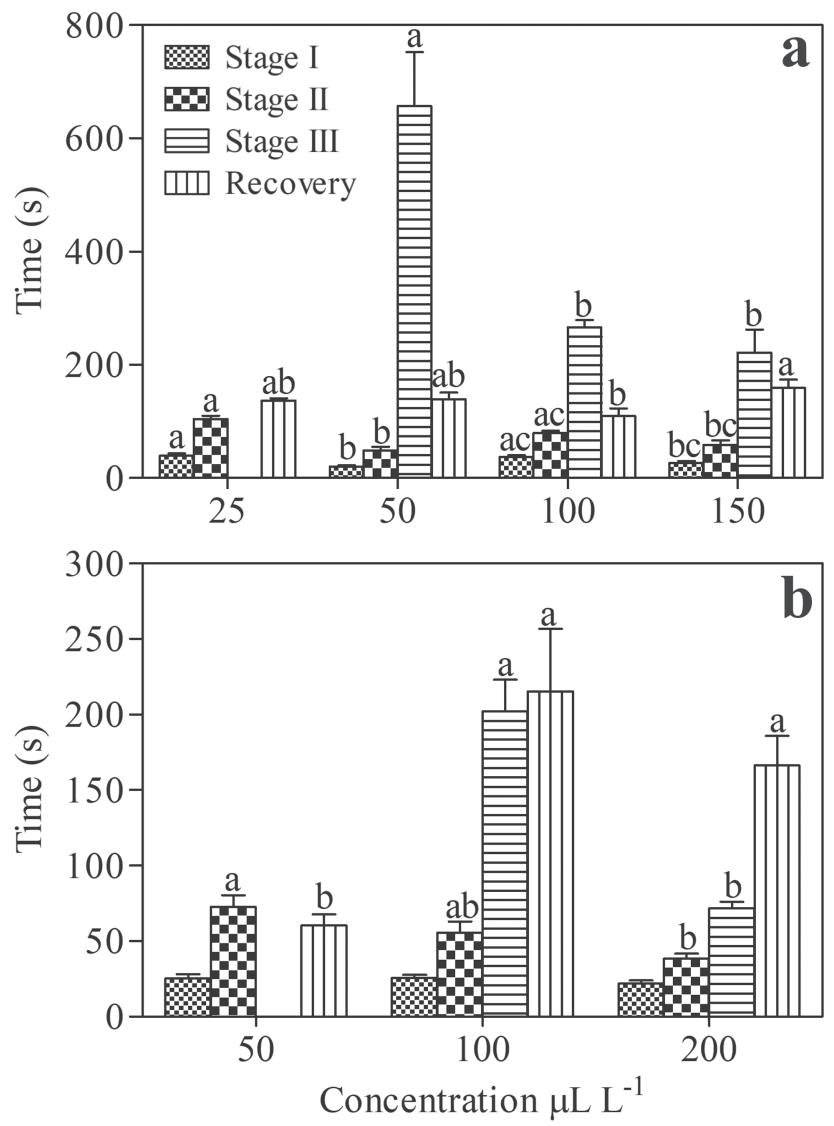

Fig. 1. Time required for induction and recovery of anesthesia in Serrasalmus eigenmanni. a. Aloysia triphylla essential oil. b. Lippia alba essential oil. Different letters indicate significant differences at each stage between treatments based on one-way ANOVA and Tukey tests $(\mathrm{P}<0.05)$. 
In the second experiment, fish exposed to 3 and 5 $\mu \mathrm{L} \mathrm{L}^{-1}$ A. triphylla $\mathrm{EO}$ and 5 and $10 \mu \mathrm{L} \mathrm{L}^{-1}$ L. alba $\mathrm{EO}$ presented lower swimming times than control fish over all analyzed times. Out of all the fish exposed to $10 \mu \mathrm{L} \mathrm{L}^{-1}$ L. alba EO, $22.22 \%$ showed a loss of equilibrium after 1 $\mathrm{h}$ of exposure. The fish did not show a loss of equilibrium in the other tested concentrations of both EOs. Ethanolexposed fish showed lower swimming times compared to control fish in the first $5 \mathrm{~min}$ and in the last $60 \mathrm{~min}$ of exposure (Fig. 2).
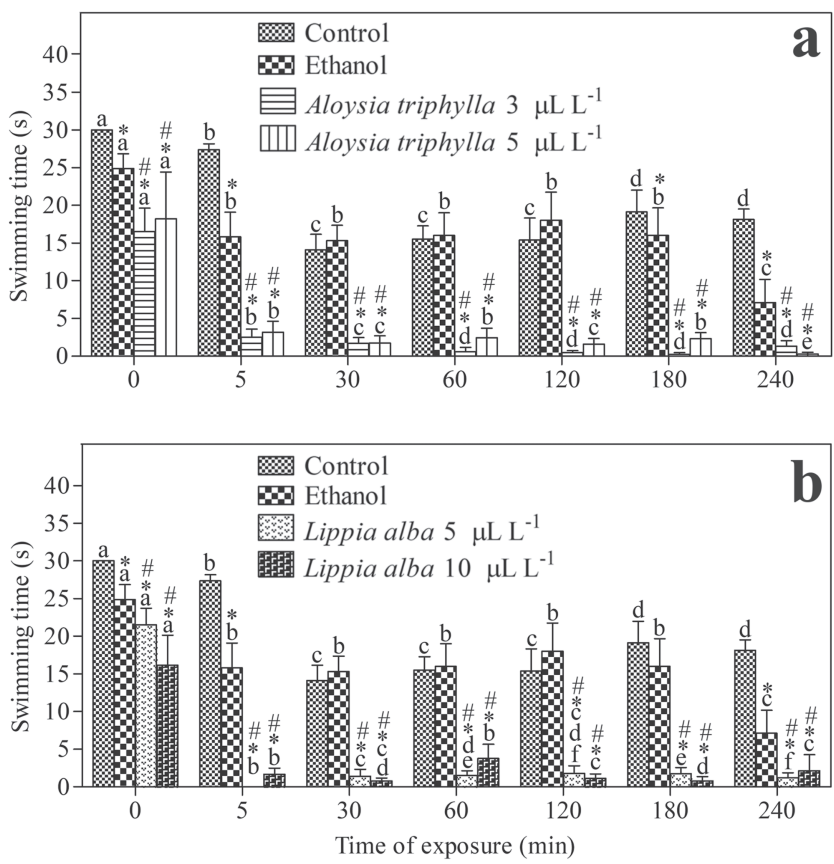

Fig. 2. Swimming time of Serrasalmus eigenmanni exposed to a. A. triphylla essential oil. b. L. alba essential oil. Different letters indicate significant differences at each exposure time between treatments based on the non-parametric Scheirer-Ray-Hare extension of the Kruskal-Wallis test, followed by a post-hoc Nemenyi test. * indicates a significant difference from control fish. \# indicates a significant difference from ethanolexposed fish.

There was no significant difference in net ion $\mathrm{Na}^{+}$, $\mathrm{K}^{+}$and $\mathrm{Cl}^{-}$) fluxes, except at $3 \mu \mathrm{L} \mathrm{L}^{-1} A$. triphylla $\mathrm{EO}$, in which the $\mathrm{K}^{+}$efflux was lower compared to ethanolexposed fish (Fig. 3).

Ammonia excretion did not differ between treatments, except at $5 \mu \mathrm{L} \mathrm{L}^{-1} A$. triphylla $\mathrm{EO}$, in which ammonia excretion was lower than ethanol-exposed and control fish (Fig. 4).

The plasma levels of cortisol, total T4, glucose, lactate and lipids showed no significant differences across all treatments. Protein levels decreased in fish exposed to $5 \mu \mathrm{L} \mathrm{L}^{-1}$ L. alba EO compared to control and ethanolexposed fish (Tab. 1).
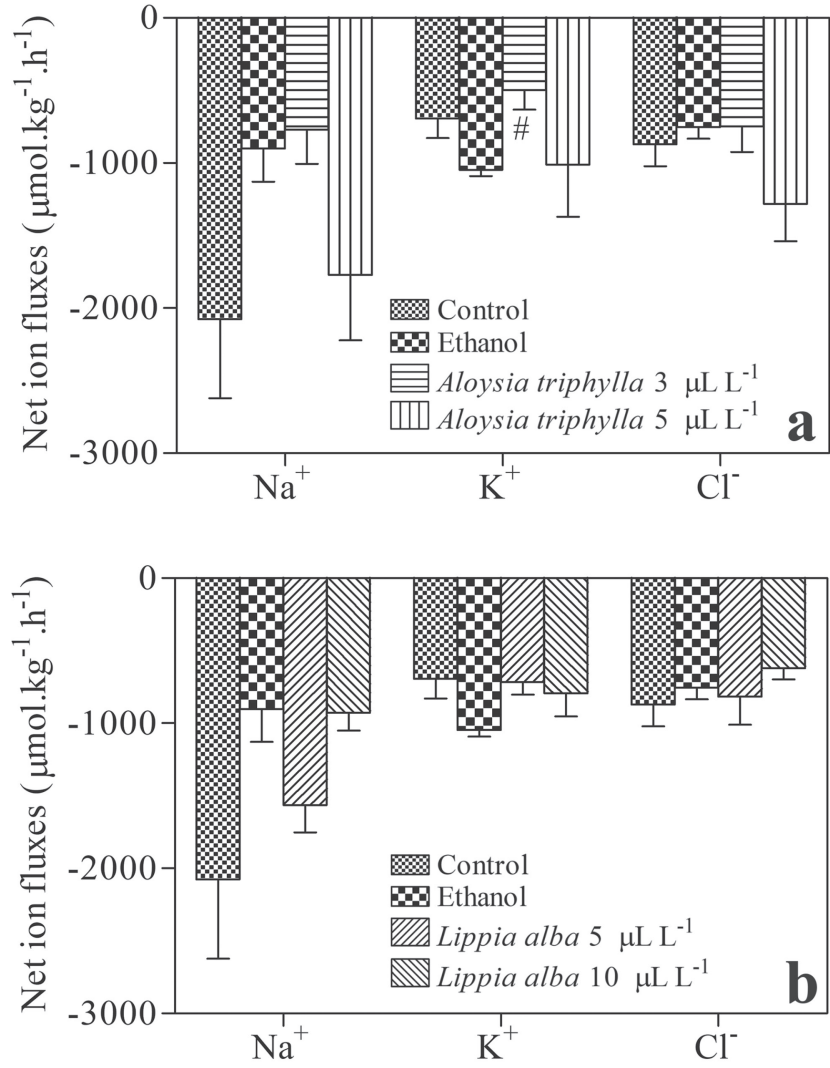

Fig. 3. Net ion fluxes of Serrasalmus eigenmanni exposed to essential oils for 4 hours. a. A. triphylla essential oil. b. L. alba essential oil. \# indicates a significant difference from ethanol-exposed fish, based on one-way ANOVA and Tukey tests $(\mathrm{P}<0.05)$.

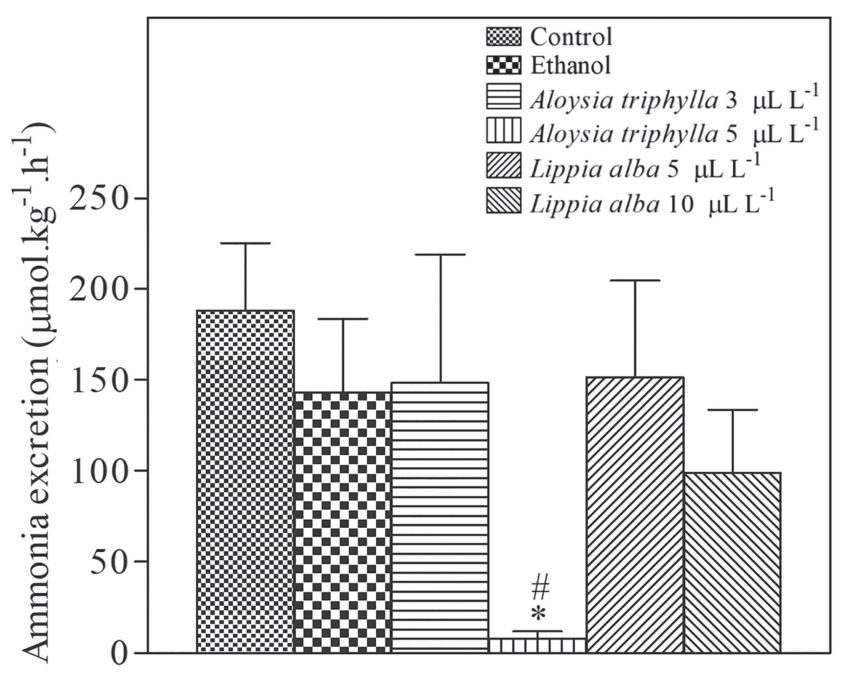

Fig. 4. Ammonia excretion of Serrasalmus eigenmanni exposed to essential oils for 4 hours. a. A. triphylla essential oil. b. L. alba essential oil. * indicates a significant difference from control fish and \# indicates a significant difference from ethanol-exposed fish, based on one-way ANOVA and Tukey tests $(\mathrm{P}<0.05)$. 
Tab. 1. Plasma levels of cortisol $\left(\mu \mathrm{g} \mathrm{dL} \mathrm{L}^{-1}\right)$, total $\mathrm{T} 4(\mu \mathrm{g} \mathrm{dL}-1)$, glucose $\left(\mathrm{mg} \mathrm{dL}^{-1}\right)$, lactate $\left(\mathrm{mg} \mathrm{dL}^{-1}\right)$, protein $\left(\mathrm{mg} \mathrm{mL}^{-1}\right)$ and lipids ( $\left.\mathrm{mg} \mathrm{mL}^{-1}\right)$ in Serrasalmus eigenmanni exposed to different concentrations of Aloysia triphylla and Lippia alba essential oils. * indicates a significant difference from control fish and \# indicates a significant difference from ethanol-exposed fish, based on one-way ANOVA and Tukey tests $(\mathrm{P}<0.05)$.

\begin{tabular}{lcccccc}
\hline Treatment & Cortisol & Total T4 & Glucose & Lactate & Protein & Lipids \\
\hline Control & $83.21 \pm 16.06$ & $15.55 \pm 5.31$ & $79.79 \pm 8.98$ & $21.10 \pm 2.83$ & $70.15 \pm 2.40$ & $11.65 \pm 0.79$ \\
Ethanol & $38.40 \pm 5.07$ & $17.64 \pm 5.69$ & $82.92 \pm 7.02$ & $63.34 \pm 19.67$ & $69.08 \pm 6.57$ & $11.28 \pm 1.51$ \\
Lippia alba $5 \mu \mathrm{L} \mathrm{L}^{-1}$ & $81.60 \pm 6.48$ & $12.55 \pm 1.75$ & $55.10 \pm 4.92$ & $35.78 \pm 20.80$ & $40.59 \pm 4.46^{* \#}$ & $11.03 \pm 1.66$ \\
Lippia alba $10 \mu \mathrm{L} \mathrm{L}^{-1}$ & $70.00 \pm 9.90$ & $20.90 \pm 1.54$ & $82.33 \pm 5.76$ & $31.07 \pm 10.95$ & $60.8 \pm 10.19$ & $11.80 \pm 0.47$ \\
Aloysia triphylla $3 \mu \mathrm{L} \mathrm{L}^{-1}$ & $47.22 \pm 9.34$ & $4.43 \pm 2.70$ & $64.32 \pm 7.81$ & $43.70 \pm 22.62$ & $67.57 \pm 7.50$ & $9.26 \pm 0$ \\
\hline
\end{tabular}

\section{Discussion}

Fish are exposed to several stressors during their life cycle, both in the natural environment and on fish farms. Anesthetic substances are used to prevent or reduce stress damage in cultured fish. According to Ross (2008), the maximum acceptable time to induce deep anesthesia is 600 s. The present study showed that both EOs induced deep anesthesia in S. eigenmanni in less than $600 \mathrm{~s}$; therefore, they can be used as anesthetics in this species. There are no studies of the anesthetic efficacy of geranial, limonene, and cis-carveol ( $Z$-carveol) in fish, the main compounds of $A$. triphylla EO, but other EOs that anesthetize fish also contain these compounds in different amounts (Hoseini et al., 2018; Lopes et al., 2018). The anesthetic efficacy of linalool and eucalyptol (syn 1,8-cineole), the main compounds of $L$. alba $\mathrm{EO}$, was determined for $R$. quelen (Heldwein et al., 2014) and Oncorhynchus mykiss (Mirghaed et al., 2018), respectively; the anesthetic efficacy of both compounds was also determined for Cyprinus carpio (Mazandarani et al., 2017; Khumpirapang et al., 2018). The anesthetic effects of these EOs are due to the association of these main compounds (and maybe other minor compounds) and result from additive and/or synergistic activities.

The lower concentrations of A. triphylla and L. alba EOs, $25 \mu \mathrm{L} \mathrm{L}^{-1}$ and $50 \mu \mathrm{L} \mathrm{L}^{-1}$, respectively, induced only the sedation stage in which fish presented a low reactivity to external stimuli and a partial loss of equilibrium. The more efficient concentration for rapid deep anesthesia in $S$. eigenmanni was $100 \mu \mathrm{LL}^{-1}$ A. triphylla $\mathrm{EO}$, with an induction time of $266 \mathrm{~s}$ and a recovery time of $110 \mathrm{~s}$; increasing the concentration to $150 \mu \mathrm{L} \mathrm{L}^{-1}$ did not reduce the time to reach deep anesthesia. The recommended concentration for deep anesthesia in both the albino and gray strains of $R$. quelen $\left(2.6-3.0 \mathrm{~g}, 24^{\circ} \mathrm{C}, \mathrm{pH} 7.0\right)$ and in C. parallelus $(2.7$ g, 30 ppt seawater, $23{ }^{\circ} \mathrm{C}$ ) is $200 \mu \mathrm{L} \mathrm{L}^{-1}$ with the same EO (Parodi et al. 2014, 2016), while for $S$. rhombeus (110.9 g, $30^{\circ} \mathrm{C}, \mathrm{pH} 5.0$ ), it is $150 \mu \mathrm{L} \mathrm{L}^{-1}$ (Almeida et al., 2018); these species need a concentration higher than that required for the deep anesthesia of $S$. eigenmanni. In the case of $L$. alba $\mathrm{EO}$, the best concentration to induce deep anesthesia in S. eigenmanni was also $100 \mu \mathrm{L} \mathrm{L}^{-1}$, with induction and recovery times of $236 \mathrm{~s}$ and $242 \mathrm{~s}$, respectively. Serrasalmus eigenmanni needs a lower L. alba EO concentration for the same anesthesia induction time as $S$. rhombeus $(110.9 \mathrm{~g}, 30$ ${ }^{\circ} \mathrm{C}, \mathrm{pH}$ 5.0; $200 \mu \mathrm{L} \mathrm{L}^{-1}$; Almeida et al. (2018)), Nile tilapia Oreochromis niloticus $\left(4.2,25^{\circ} \mathrm{C}, \mathrm{pH} 7.5\right.$; approximately $450 \mu \mathrm{L} \mathrm{L}^{-1}$; Hohlenwerger et al. (2016)) and silver catfish $R$. quelen $\left(6.5 \mathrm{~g}, 21^{\circ} \mathrm{C}\right.$, $\mathrm{pH}$ 6.5-7.0; approximately $450 \mu \mathrm{L} \mathrm{L}^{-1}$; Cunha et al. (2010)), but a similar concentration as tambacu, the hybrid of Piaractus mesopotamicus $\times$ Colossoma macropomum $\left(72.8 \mathrm{~g}, 26^{\circ} \mathrm{C}, \mathrm{pH} 7.5 ; 200 \mu \mathrm{L} \mathrm{L}^{-1}\right.$; Sena et al. (2016)). As these studies with the EOs of $A$. triphylla and $L$. alba were performed with the same chemotypes, i.e., similar compositions, differences in the best concentrations to induce deep anesthesia are probably related to the different temperatures, $\mathrm{pH}$, fish size, and/or species used. These water parameters can change the efficacy of the EOs (Hoseini et al., 2018).

In the second experiment, low concentrations were tested to verify the viability of the use of these EOs for the transport of S. eigenmanni. The lower swimming activity of the fish when exposed to the EOs is an indication that these products can be recommended for the transport of Amazon fish at high temperatures. For fish transport, it is recommended that animals remain in the deep sedation stage, in which there is a loss of responsiveness to external stimuli, but without the loss of equilibrium and supposedly with lower metabolic activity (Summerfelt, Smith, 1990; Pirhonen, Schreck, 2003). The equilibrium loss of $22.22 \%$ of fish after $1 \mathrm{~h}$ of exposure suggests that the concentration of $10 \mu \mathrm{L} \mathrm{L}^{-1}$ of $L$. alba EO cannot be used for fish transport at high temperatures, because according to Cooke et al. (2014), in this stage, the fish may die of suffocation.

In stressful situations, the organism responds with the sympathetic activation of the hypothalamic-hypophysisinterrenal (HHI) axis, which triggers a change in the blood hormone levels, mainly catecholamines secreted by the chromaffin cells and the release of cortisol by the interrenal tissue (Mazeaud et al., 1977; Barton, Iwama, 1991; Barton, 2002). Consequently, metabolic changes, such as the increase of glucose, lactate, and tyrosine (T4) and a decrease in protein levels, as well as ionoregulatory disorders (Barton, 2002), may occur.

The addition of EOs of A. triphylla and L. alba to the transport water of silver catfish $R$. quelen showed that these EOs minimized stress transport effects through the reduction of cortisol release, ammonia excretion and ion loss (Becker 
et al., 2012, 2013; Parodi et al., 2014; Zeppenfeld et al., 2014). The addition of $20 \mu \mathrm{L} \mathrm{L}^{-1}$ of $A$. triphylla $\mathrm{EO}$ in the transport water of $C$. paralellus decreased cortisol plasma levels and ammonia excretion (Parodi et al., 2016). The catching of $S$. eigenmanni specimens from the maintenance tanks and their transfer to the experimental aquaria led to a net ion loss to the water in the first few hours after handling. Similar results were found in a previous study with the same species (Baldisserotto et al., 2008a) and other Amazonian fish in blackwater (Baldisserotto et al., 2008b). The metabolic parameters, ammonia excretion, and ion fluxes of $S$. eigenmanni were not affected by exposure to EOs, except at 3 and $5 \mu \mathrm{L} \mathrm{L}^{-1}$ of $A$. triphylla $\mathrm{EO}$, in which there was a reduction of $\mathrm{K}^{+}$efflux (compared to ethanol-exposed fish) and ammonia excretion, respectively. The decrease of ammonia excretion may be related to metabolism reduction, in accordance with the lower swimming activity in $S$. eigenmanni induced by this EO. Lower ammonia excretion was also observed in silver catfish (Zeppenfeld et al., 2014) and C. paralellus transported with this EO (Parodi et al., 2016). On the other hand, Mazandarani et al. (2016) attributed the lower ammonia excretion, associated with higher serum urea levels in common carp Cyprinus carpio transported with linalool (the main constituent of the $L$. alba EO), as a sign of impaired gill function. Additional studies analyzing plasma ammonia and urea levels in fish transported with A. triphylla and L. alba EOs will provide more insight into this phenomenon.

Regarding the active substances of the studied EOs, literature reports demonstrated central depressor effects for geranial, limonene, and linalool in in vivo and ex vivo rodent models (Vale et al., 1999, 2002; Sousa et al., 2015), and also for linalool in fish (Heldwein et al., 2014). In addition, carveol itself did not induce anesthesia, but enhanced the anesthetic effects of propofol in mice (Lin et al., 2006). As such, the available information indicates that the observed effects may result from the interaction of the different EO components.

In conclusion, both EOs showed anesthetic effects in $S$. eigenmanni. The recommended concentrations are 25 and $50 \mu \mathrm{L} \mathrm{L}^{-1}$ for sedation and $100 \mu \mathrm{L} \mathrm{L}^{-1}$ for deep anesthesia. A $5 \mu \mathrm{L} \mathrm{L} \mathrm{L}^{-1}$ concentration of both EOs is recommended for the transport of $S$. eigenmanni lasting up to $4 \mathrm{~h}$; at this concentration, fish decreased ammonia excretion with the A. triphylla $\mathrm{EO}$ and maintained swimming equilibrium with both EOs.

\section{Acknowledgments}

The authors acknowledge the support received from INCT-ADAPTA (Conselho Nacional de Desenvolvimento Científico e Tecnológico/Fundação de Amparo à Pesquisa no Estado do Amazonas). ALV, BB and BMH received CNPq research fellowships and APGA received a CAPES, Brazil (Coordenação de Aperfeiçoamento de Pessoal de Nível Superior) PhD fellowship (Finance Code 001).

\section{References}

Almeida APG, Heinzmann BM, Val AL, Baldisserotto B. Essential oils and eugenol as anesthetics for Serrasalmus rhombeus. Bol Inst Pesca. 2018; 44(1):44-50.

Baldisserotto B, Chippari-Gomes AR, Lopes NP, Bicudo JEPW, Paula-Silva MN, Almeida-Val VMF, Val AL. Ion fluxes and hematological parameters of two teleosts from the rio Negro, Amazon, exposed to hypoxia. Braz J Biol. 2008a; 68(3):571-75.

Baldisserotto B, Copatti CE, Gomes LC, Chagas EC, Brinn RP, Roubach R. Net ion fluxes in the facultative air-breather Hoplosternum littorale (tamoata) and the obligate air-breather Arapaima gigas (pirarucu) exposed to different Amazonian waters. Fish Physiol Biochem. 2008b; 34(4):405-12.

Bandeira Junior G, Abreu MS, Rosa JGS, Pinheiro CG, Heinzmann BM, Caron BO, Baldisserotto B, Barcellos LJG. Lippia alba and Aloysia triphylla essential oils are anxiolytic without inducing aversiveness in fish. Aquaculture. 2018; 482:49-56.

Bansemir A, Blume MS, Schröder S, Lindequist U. Screening of cultivated seaweeds for antibacterial activity against fish pathogenic bacteria. Aquaculture. 2006; 252(1):79-84. Available from: https:/www.sciencedirect.com/science/ article/abs/pii/S0044848605007556

Barton BA. Stress in fish: a diversity of responses with particular reference to changes in circulating corticosteroids. Integr Comp Biol. 2002; 42(3):517-25.

Barton BA, Iwama GK. Physiological changes in fish from stress in aquaculture with emphasis on the response and effects of corticosteroids. Annu Rev Fish Dis. 1991; 11:3-26.

Becker AG, Cunha MA, Garcia LO, Zeppenfeld CC, Parodi TV, Maldaner G, Morel AF, Baldisserotto B. Efficacy of eugenol and the methanolic extract of Condalia buxifolia during the transport of the silver catfish Rhamdia quelen. Neotrop Ichthyol. 2013; 11(3):675-81.

Becker AG, Parodi TV, Heldwein CG, Zeppenfeld CC, Heinzmann BM, Baldisserotto B. Transportation of silver catfish, Rhamdia quelen, in water with eugenol and the essential oil of Lippia alba. Fish Physiol Biochem. 2012; 38(3):789-96.

Becker AG, Parodi TV, Zeppenfeld CC, Salbego J, Cunha MA, Heldwein CG, Loro VL, Heinzmann BM, Baldisserotto B. Pre-sedation and transport of Rhamdia quelen in water containing essential oil of Lippia alba: metabolic and physiological responses. Fish Physiol Biochem. 2016; 42(1):73-81.

Benovit SC, Gressler LT, Silva LL, Garcia LO, Okamoto MH, Pedron JS, Sampaio LA, Rodrigues RV, Heinzmann BM, Baldisserotto B. Anesthesia and transport of Brazilian flounder, Paralichthys orbignyanus, with essential oils of Aloysia gratissima and Ocimum gratissimum. J World Aquacult Soc. 2012; 43(6):896-900.

Boijink CL, Queiroz CA, Chagas EC, Chaves FCM, Inoue LAKA. Anesthetic and anthelminthic effects of clove oil basil (Ocimum gratissimum) essential oil for tambaqui (Colossoma macropomum). Aquaculture. 2016; 457:24-28. 
Cárdenas C, Toni C, Martos-Sitcha JA, Cardenas S, de las Heras V, Baldisserotto B, Heinzmann BM, Vazquez R, Mancera JM. Effects of clove oil, essential oil of Lippia alba and 2-phe anaesthesia on juvenile meagre, Argyrosomus regius (Asso, 1801). J Appl Ichthyol. 2016; 32(4):693-700.

Cooke SJ, Suski CD, Ostrand KG, Tufts BL, Whal DH. Behavioral and physiological assessment of low concentrations of clove oil anaesthetic for handling and transporting largemouth bass (Micropterus salmoides). Aquaculture. 2004; 239(1-4):509-29.

Cunha MA, Barros FMC, Garcia LO, Veeck APL, Heinzmann BM, Loro VL, Emanuelli T, Baldisserotto B. Essential oil of Lippia alba: a new anesthetic for silver catfish, Rhamdia quelen. Aquaculture. 2010; 306(1-4):403-06.

Cunha MA, Silva BF, Delunardo FAC, Benovit SC, Gomes LC, Heinzmann BM, Baldisserotto B. Anesthetic induction and recovery of Hippocampus reidi exposed to the essential oil of Lippia alba. Neotrop Ichthyol. 2011; 9(3):683-88.

Dórea JG, Barbosa AC, Souzade J, Fadini P, Jardim WF. Piranhas (Serrasalmus spp.) as markers of mercury bioaccumulation in Amazonian ecosystems. Ecotox Environ Safe. 2004; 59(1):57-63.

Eaton AD, Clesceri LS, Rice EW, Greenberg AE, Franson MAH, editors. Standard methods for the examination of water and wastewater. Centennial Edition. 21st ed. Washington: American Public Health Association, American Water Works Association and Water Environment Federation; 2005.

Fonseca OJM, Salem JI, Guarim VL. Poluição e autopurificação do Rio Negro nas cercanias de Manaus. Acta Amaz. 1982; 12(2):271-78.

Frings CS, Fendley TW, Dunn RT, Queen CA. Improved determination of total serum lipids by the sulfo-phosphovanillin reaction. Clin Chem. 1972; 18(7):673-74.

Gomes DP, Chaves BW, Becker AG, Baldisserotto B. Water parameters affect anaesthesia induced by eugenol in silver catfish, Rhamdia quelen. Aquacult Res. 2011; 42(6):878-86.

Gressler LT, Riffel APK, Parodi TV, Saccol EMH, Koakoski G, Costa ST, Pavanato MA, Heinzmann BM, Caron B, Schmidt D, Llesuy SF, Barcellos LJG, Baldisserotto B. Silver catfish Rhamdia quelen immersion anaesthesia with essential oil of Aloysia triphylla (L'Hérit) Britton or tricaine methanesulfonate: effect on stress response and antioxidant status. Aquacult Res. 2014; 45(6):1061-72.

Gutmann I, Wahlefeld W. L-(+)-Lactate: determination with lactate dehydrogenase and NAD. In: Bergmeyer HU, editor. Methods of enzymatic analysis: volume 2. 2nd ed. New York: Verlag Chemie-Academic Press; 1974. p.1464-1472.

Heldwein CG, Silva LL, Gai EZ, Roman C, Parodi TV, Bürger ME, Baldisserotto B, Flores EMM, Heinzmann BM. $S$-(+)-Linalool from Lippia alba: sedative and anesthetic for silver catfish (Rhamdia quelen). Vet Anaesth Analg. 2014; 41(6):621-29. Available from: https://onlinelibrary.wiley.com/doi/10.1111/ vaa. 12146

Hohlenwerger JC, Copatti CE, Sena AC, Couto RD, Baldisserotto B, Heinzmann BM, Caron BO, Schmidt D. Could the essential oil of Lippia alba provide a readily available and cost-effective anaesthetic for Nile tilapia (Oreochromis niloticus)? Mar Freshwater Behav Physiol. 2016; 49(2):119-26.
Hoseini SA, Mirghaed AT, Yousefi M. Application of herbal anesthetics in aquaculture. Rev Aquacult. 2018; 0:1-15. Available from: https://doi.org/10.1111/raq.12245

Jégu M. Subfamily Serrasalminae (Pacus and piranhas). In: Reis RE, Kullander SO, Ferraris CJ, Jr., organizers. Check list of the freshwater fishes of South and Central America. Porto Alegre: Edipucrs; 2003. p.182-196.

Khumpirapang N, Chaichit S, Jiranusornkul S, Pikulkaew S, Müllertz A, Okonogi S. In vivo anesthetic effect and mechanism of action of active compounds from Alpinia galangal oil on Cyprinus carpio (koi carp). Aquaculture. 2018; 496:176-84.

Küchler IL, Miekeley N, Forsberg BR. A contribution to the chemical characterization of rivers in the Rio Negro basin, Brazil. J Braz Chem Soc. 2000; 11(3):286-92.

Lin AL, Shangari N, Chan TS, Remirez D, O'Brien PJ. Herbal monoterpene alcohols inhibit propofol metabolism and prolong anesthesia time. Life Sci. 2006; 79(1):21-29.

Lopes JM, Souza CD, Schindler B, Pinheiro CG, Salbego J, Siqueira JC, Heinzmann BM, Baldisserotto B. Essential oils from Citrus $x$ aurantium and Citrus $x$ latifolia (Rutaceae) have anesthetic activity and are effective in reducing ion loss in silver catfish (Rhamdia quelen). Neotrop Ichthyol. 2018; 16(2):e170152.

Lowry OH, Rosebrough NJ, Farr AL, Randall RJ. Protein measurement with the folin phenol reagent. J Biol Chem. 1951; 193:265-75.

Matsuo AYO, Val AL. Acclimation to humic substances prevents whole body sodium loss and stimulates branchial calcium uptake capacity in cardinal tetras Paracheirodon axelrodi (Schultz) subjected to extremely low pH. J Fish Biol. 2007; 70(4):989-1000.

Mazandarani M, Hoseini SM. Anesthesia of juvenile Persian sturgeon, Acipenser persicus; Borodin 1897, by peppermint, Mentha piperita, extract - anesthetic efficacy, stress response and behavior. Int J Aquat Biol. 2017; 5(6):393-400.

Mazandarani M, Hoseini SM, Ghomshani MD. Effects of linalool on physiological responses of Cyprinus carpio (Linnaeus, 1758) and water physico-chemical parameters during transportation. Aquacult Res. 2017; 48(12):5775-81.

Mazeaud MM, Mazeaud F, Donaldson EM. Primary and secondary effects of stress in fish: some new data with a general review. Trans Am Fish Soc. 1977; 106(3):201-12.

Ministério da Agricultura, Pecuária e Abastecimento (MAPA). Instrução Normativa Interministerial No 28 de 08 de Junho de 2011. Brasília, DF; 2011. Available from: http://www. agricultura.gov.br/assuntos/sustentabilidade/organicos/ legislacao/portugues/instrucao-normativa-interministerialno-28-de-08-de-junho-de-2011-producao-de-organismosaquaticos.pdf/view

Mirghaed AT, Ghelichpour M, Zargari A, Yousefi M. Anaesthetic efficacy and biochemical effects of 1,8-cineole in raibow trout (Oncorhynchus mykiss, Walbaum, 1792). Aquacult Res. 2018; 49(6):2156-65.

Mortatti J, Probst JL. Silicate rock weathering and atmospheric/soil $\mathrm{CO}_{2}$ uptake in the Amazon basin estimated from river water geochemistry: seasonal and spatial variations. Chem Geol. 2003; 197(1-4):177-96. 
Parodi TV, Cunha MA, Becker AG, Zeppenfeld CC, Martins DI, Koakoski G, Barcellos LG, Heinzmann BM, Baldisserotto B. Anesthetic activity of the essential oil of Aloysia triphylla and effectiveness in reducing stress during transport of albino and gray strains of silver catfish, Rhamdia quelen. Fish Physiol Biochem. 2014; 40(2):323-34.

Parodi TV, Santos CA, Veronez A, Gomes LC, Heinzmann BM, Baldisserotto B. Anesthetic induction and recovery time of Centropomus parallelus exposed to the essential oil of Aloysia triphylla. Cienc Rural. 2016; 46(12):2142-47.

Pirhonen J, Schreck CB. Effects of anesthesia with MS-222, clove oil and $\mathrm{CO}_{2}$ on feed intake and plasma cortisol in steelhead trout (Oncorhynchus mykiss). Aquaculture. 2003; 220(1-4):507-14.

Pramod PK, Ramachandran A, Sajeevan TP, Thampy S, Pai SS. Comparative efficacy of MS-222 and benzocaine as anaesthetics under simulated transport conditions of a tropical ornamental fish Puntius filamentosus (Valenciennes). Aquacult Res. 2010; 41(2):309-14.

Readman GD, Owen SF, Murrell JC, Knowles TG. Do fish perceive anaesthetics as aversive? PLos One. 2013; 8(9):e73773.

Ross LG, Ross B, editors. Anaesthetic and sedative techniques for aquatic animals. 3rd ed. Oxford: Blackwell Publishing; 2008.

Sampaio FDF, Freire CA. An overview of stress physiology of fish transport: changes in water quality as a function of transport duration. Fish Fish. 2016; 17(4):1055-72.

Sena AC, Teixeira RR, Ferreira EL, Heinzmann BM, Baldisserotto B, Caron BO, Schmidt D, Couto RD, Copatti CE. Essential oil from Lippia alba has anaesthetic activity and is effective in reducing handling and transport stress in tambacu (Piaractus mesopotamicus x Colossoma macropomum). Aquaculture. 2016; 465:374-79.

Silva LL, Parodi TV, Reckziegel P, Garcia VO, Bürger ME, Baldisserotto B, Malmann CA, Pereira AMS, Heinzmann BM. Essential oil of Ocimum gratissimum L.: anesthetic effects, mechanism of action and tolerance in silver catfish, Rhamdia quelen. Aquaculture. 2012; 350-353:91-97.

Silva LL, Silva DT, Garlet QI, Cunha MA, Mallmann CA, Baldisserotto B, Longhi SJ, Pereira AMS, Heinzmann BM. Anesthetic activity of Brazilian native plants in silver catfish (Rhamdia quelen). Neotrop Ichthyol. 2013; 11(2):443-51.

Small BC. Anesthetic efficacy of metomitade and comparison of plasma cortisol responses to tricaine methanesulfonate, quinaldine and clove oil anesthetized channel catfish Ictalurus punctatus. Aquaculture. 2003; 218(1-4):177-85.

Sneddon LU. Clinical anesthesia and analgesia in fish. J Exot Pet Med. 2012; 21(1):32-43.

Sousa DG, Sousa SDG, Silva RER, Silva-Alves KS, Ferreira-daSilva FW, Kerntopf MR, Menezes IRA, Leal-Cardoso JH, Barbosa R. Essential oil of Lippia alba and its main constituent citral block the excitability of rat sciatic nerves. Braz J Med Biol Res. 2015; 48(8):697-702.
Summerfelt RC, Smith LS. Anaesthesia, surgery and related techniques. In: Schreck CB, Moyle PB, editors. Methods for fish biology. Bethesda, MD: American Fisheries Society; 1990. p.213-272.

Tondolo JSM, Amaral LP, Simões LN, Garlet QI, Schindler B, Oliveira TM, Silva BF, Gomes LC, Baldisserotto B, Mallmann CA, Heinzmann BM. Anesthesia and transport of fat snook Centropomus parallelus with the essential oil of Nectandra megapotamica (Spreng.) Mez. Neotrop Ichthyol. 2013; 11(3):667-74.

Weber RA, Peleteiro JB, García Martín LO, Aldegunde M. The efficacy of 2-phenoxyethanol, metomidate, clove oil and MS-222 as anesthetic agents in the Senegalese sole (Solea senegalensis Kaup 1858). Aquaculture. 2009; 288(1-2):14750 .

Val AL, Gonzalez RJ, Wood CM, Wilson RW, Patrick ML, Bergman HL, Narahara A. Effects of water $\mathrm{pH}$ and calcium concentration on ion balance in fish of the Rio Negro, Amazon. Physiol Zool. 1998, 71(1):15-22.

Vale TG, Furtado EC, Santos Jr JG, Viana GSB. Central effects of citral, myrcene and limonene, constituents of essential oil chemotypes from Lippia alba (Mill.) n.e. Brown. Phytomedicine. 2002; 9(8):709-14.

Vale TG, Matos FJA, Lima TCM, Viana GSB. Behavioral effects of essential oils from Lippia alba (Mill.) n.e. Brown chemotypes. J Ethnopharmacol. 1999; 67(2):127-33.

Yousefi M, Hoseinifar SH, Ghelichpour M, Hoseini SM. Anesthetic efficacy and biochemical effects of citronellal and linalool in common carp (Cyprinus carpio Linnaeus, 1758) juveniles. Aquaculture. 2018; 493:107-12.

Zahl IH, Samuelsen O, Kiessling A. Anesthesia of farmed fish: Implications for welfare. Fish Physiol Biochem. 2012; 38(1):201-18.

Zall DM, Fisher D, Garder MQ. Photometric determination of chlorides in water. Anal Chem. 1956; 28(11):1665-68.

Zeppenfeld CC, Toni C, Becker AG, Miron SD, Parodi TV, Heinzmann BM, Barcellos LJG, Koakosky G, Rosa JGS, Loro VL, Cunha MA, Baldisserotto B. Physiological and biochemical responses of silver catfish, Rhamdia quelen, after transport in water with essential oil of Aloysia triphylla (L'Herit) Britton. Aquaculture. 2014; 418-419:101-07. 